\title{
LA POLÍTICA TEATRAL \\ DE LA GENERALITAT REPUBLICANA (1931-1936): REALITZACIONS I DEBATS
}

FRANCESC FOGUET

\section{ABSTRACT}

Between 1931 and 1936, the Republican Generalitat articulated its theater policy as part of an ambitious cultural plan designed with institutionalization in as part of an ambitious cultural plan designed with institutionalization in
mind. This arcicle analyzes the approach of the Catalan government with regard to the theater and considers the intense debates generated by its policies -with specific emphasis on the gap between intentions and results. The convulsive political circumstances of the moment, the insufficiencies and incompetence of the Generalitat, the general state crisis of the European theater scene, and the specific problems of the Catalan stage made it necessary to lower the ideal expectations originally proposed and with which it aspired to create "theatrical institution" "either through the nationalization of theaters, or through the creation fon the ground up of a National Theater of Cathlung. Yeut the cretor from being able to bring these projects to fruition, the Catalan government had to limit itself to guaranteeing, through the funding of companies, the promotion of the Ignasi Iglésias Prize, or the reorganization of the Institució del Teatre, a minimum degree of stability and public presence of the Catalan theater scene within the cultural system of the period.

En aquest moment històric no hi ha cap país a Europa que hagi deixat de comprendre com el teatre es vincula a l'existència nacional i com és necessari, enmig de la crisi, l'auxili de l'Estat... I si els pobles adults, sense problemes de reivindicació nacional, realitzen aquests esforços, com podríem nosaltres plegar-nos de braços refiats de la iniciativa particular que enlloc abasta i que per a Catalunya s'ha manifestat importantíssima?

Carles Soldevila

La política teatral que endegà la Generalitat de Catalunya durant els anys 1931-1936 fou més de projectes que no pas de realitzacions. Les intermitències causades per una conjuntura política convulsa, la crisi profunda que patia l'escena catalana des de dècades enrere i la seva endèmica feblesa estructural podrien, si més no, justificar-ho amb escreix. Així i tot, cal tenir present que la recuperació d'unes institucions pròpies de govern permetia d'articular, per primer cop, una mínima política teatral. L'objectiu prioritari era oficialitzar el teatre català 
d'acord amb uns plantejaments programàtics - ja esgrimits pels modernistes- que s'inspiraven en les cultures escèniques europees més consolidades i que, al capdavall, tenien com a fita la creació d'una estructura institucional bàsica.

Als condicionants interns d'un sistema teatral precari i als trasbalsos del moment històric, que dificultaren d'emprendre accions d'una certa envergadura, caldria afegir-hi la mancança pressupostària intrínseca amb què es trobà la Generalitat republicana i, naturalment, els errors comesos, les indecisions, les urgències $i$, en el cas del titular de Cultura, Ventura Gassol, la seva tendència als inflaments retòrics i als entusiasmes exagerats que poc s'avenien amb la situació real, tan sotmesa a les vicissituds polítiques. L'autor de Les tombes flamejants insistia sovint en la idea que la Generalitat havia estimulat les arts a partir de la convicció que l'obra de cultura d'un govern no podia cenyir-se exclusivament a l'escola, centre d'interès de la política cultural republicana, sinó que havia d'estendre's "a totes aquelles manifestacions de l'esperit que puguin crear un ambient cultural per tot el país" (Gassol 5). El benintencionat discurs del conseller de Cultura situava e teatre com a part d'una política cultural nacional, d'abast ampli i de signe clarament institucionalitzador.

Al cap de nou mesos d'instaurades la Generalitat de Catalunya i les seves institucions, Gassol ressenyà l'obra de cultura duta a terme pel govern català (en els àmbits de l'ensenyament, la universitat i els arxius les biblioteques) $i$ apuntà la que pensava acomplir en el futur. Entre les accions que es volien escometre en matèria teatral i que s'havien proposat ja al Consell de Cultura cal remarcar la voluntat de crear uns premis anuals de literatura i acompanyar-los de la celebració d'unes festes artístiques per donar-los visibilitat pública, d'una banda, i, de l'altra, la intenció de nacionalitzar tres teatres: "un de drama, un d'opereta i un de gran òpera, com en els països de cultura perfectament organitzada", ja que es considerava que "sense aquesta nacionalització fóra gairebé impossible que el teatre de casa nostra deixés de viure aquesta vida migrada que ens avergonyeix" (Generalitat, L'obra 243).

Des del penal de Cartagena, on fou reclòs amb el president Lluís Companys i altres consellers del seu govern arran del Sis d'Octubre de 1934, Gassol féu, el to de febrer de 1936, un balanç apassionat de l'obra realitzada pel govern de la Generalitat des de la proclamació de la República fins al 6 octubre, en el qual destacava el patrocini moral econòmic al teatre català $\mathrm{amb}$ la collaboració de l'Ajuntament de Barcelona. Gassol posava com a mostra la contribució al redreçament del Gran Teatre del Liceu, en un moment en què estava a punt de tancar les portes, la creació del Comitè de Teatre i del Comitè del Liceu, la institucionalització del premi Ignasi Iglésias i la reorganització de la Institució del Teatre, entre altres realitzacions (Gassol). ${ }^{\text {I Es tractava de }}$ mesures, tot just encetades, que aspiraven a cobrir tots els flancs possibles en el camí de la institucionalització de la cultura en general i del teatre en particular.

Recuperada la normalitat estatutària amb la victòria de les esquerres a les eleccions del febrer de 1936, Gassol pronuncià un encès parlament en pro del teatre català en el banquet d'homenatge als actors Maria Vila i Pius Daví, que tingué lloc l'is de juny de 1936 al restaurant La Cala ("A tots els pobles"). En el seu discurs, el titular de Cultura tornà a insistir en la importància que tenia el teatre i en la necessitat de treballar per la seva institucionalització, per tal com Catalunya no podia gaudir d'una "cultura completa" sense la "institució teatral" que era l'"ànima" del poble i que esdevenia ineludible per a la "cultura general”. La voluntat institucionalitzadora del govern català d'esquerres era ben clara, però la capacitat d'actuació es veié considerablement limitada, com veurem, per una conjuntura política i social adversa.

\section{REALITZACIONS}

La iniciativa més agosarada de la política teatral del conseller Gassol fou la constitució del Comitè de Teatre de la Generalitat de Catalunya, el gener de 1934. Presidit per Ventura Gassol i Carles Pi i Sunyer, aquest darrer com a alcalde de Barcelona, el nou organisme era integrat per noms de prestigi com ara Josep M. Millàs-Raurell, Alexandre Plana, Josep Pous i Pagès, Joan Puig i Ferreter o Josep Maria de Sagarra, i tenia com a finalitat d'organitzar, sota el patronatge de la Generalitat i de l'Ajuntament, el funcionament de les temporades oficials a Barcelona - i la seva extensió a les comarques - a càrrec d'una companyia subvencionada que guanyés el concurs públic obert a les empreses i entitats teatrals catalanes (Bransuela). ${ }^{2}$ Malgrat que començà a treballar un cop constituït, les circums-

'Sobre l'actuació de la Generalitat republicana en el Gran Teatre del Liceu, vegeu Foguer ("La nacionalització").

${ }^{2}$ El Comitè de Teatre estigué compost inicialment per Joan Puig i Ferreter, en representacio del Parlament de Catalunya; Antoni Ventós 1 Octavi Saltor, com a reprepremis literaris de la Generalitat; Claudi Castells, com a vocal de la Insritucio pro-Teatre Cacalà (que aglutinava les entitats Societat d'Autors de Catalunya, Sindicat d'Actors, Associació d'Artistes Lírics i Dramàtics, Sindicat Musical, Associació de Teatre Selecte $\mathrm{i}$ Federació Catalana de Societats de Teatre Amateur, entre d'altres); Joan Pous i Pagès, Josep M. de Sagarra i Joan Francesc Vidal Jové, en qualitat d'aurors; Ferran Rubió i Josep M. Roviralta, com a veins de la ciutat, i Miquel de Paloi, Domènec de Bellmunt, Pere Cavallé i Sebastià Juan Arbó (que hi acruava de secretari), en representació, respectivament, de les comarques de Girona, Lleida, Tarragona i Baix-Ebre ("Ha estat dissolt"). El Teatre no podien ser programats en el tearre oficial, a excepció feta de Vidal Jové que hi estrenaria La senyoreta Oest, per haver obringur el segon premi del concurs Ignasi Iglé- 
tàncies polítiques —els fets del Sis d'Octubre i l'esclat de la Guerra i la Revolució- donaren molt poc marge de maniobra al nounat Comitè de Teatre.

En la pràctica, la política teatral que promogué el Departament de Cultura dirigit per Gassol se centrà en tres grans eixos d'acció que tendien a oficialitzar o a renovar algunes de les iniciatives provinents del període immediatament anterior: (a) la subvenció d'una companyia de teatre perquè programés en català, a fi d'assegurar la presència del teatre indígena en la cartellera barcelonina; (b) la reorganització interna de la Institució del Teatre, $i$ (c) la continuitat sota la protecció oficial del premi Institució del Teatre, i (c) la continuitat sota la protecció oficial del premi Departament d'Instrucció, deixà sobre la taula del Consell Executiu, en la sessió de l'is de gener de 1932, un "projecte de reglamentació" per a la la sessió d'abast general, que premis de la Generalitat, d'abast general, que ja feia preveure quina seria l'orientació que prendria la política teatral republicana (Butlletí de la Generalitat de Catalunya I [I5 gener 1932]: I3).

La primera actuació efectiva s'orientà en la línia d'allò que fou l'eix principal de l'acció governativa en matèria teatral: el suport econòmic a les companyies de teatre. El 25 d'abril de 1932 , la Generalitat concedí una subvenció de ro.00o pessetes a l'empresa del Teatre Romea de Barcelona per ajudar-la a dur a terme "degudament" la temporada de teatre català per curs (BGC [Is maig I932]: 226). ${ }^{3}$ Posteriorment, de bracet amb l'Ajuntamc de Barclona entribuir amb un , el govern catala acorda de contribuir arb un ajut a l'estabilització i dignificació de l'escena catalana. El Comitè de Teatre formulà les bases per a un concurs que retribuís amb 80.000 pessetes, ampliables fins a les I00.000, l'empresa que es dignés a oferir el illor millor programa de res en concurs, les candi1935 ("La Generalitat"). Si volien prendre part en el concurs, les candidatures havien de presentar, abans de l'r de juny, un pla general de la temporada en un local de la ciutat de Barcelona (amb una durada mínima de set mesos consecutius) i de l'extensió a altres ciutats i viles de

ias. La intenció era inaugurar la temporada oficial ben aviat, probablement al Teatre Poliorama a la primavera, peró ja es prevela que s'hauria
setembre o a la primeria d'octubre de 1934 (Bransuela).

${ }^{3}$ Durant l'any 1932, la Generalitat republicana concedí també diverses subvencions a entitats teatrals perquè poguessin dur a cap les seves activitats: (a) la Institució del Teatre rebé l'import de to $3^{\prime}$ is pessetes per editar la traducció catalana de l'estudi $L a$ poesia trobadoresca, de Manuel de Montoliu ( $B G C$ S [I5 març 1932]: 131), a més de l'import de 150 pessetes per la conferència "Breu història del teatre nord-americà", que hi impartí Josep M. Millas i Raurell ( $B G C_{14}$ [30 juliol 1932]: 306 ) i de les 250 pessetes per un dibuix d'un actor en escena, original de Ramon Casas, que la Instirució adquirí a la Sala Parés (BGC I7 [Is setembre 1932]: 458), 1 (b) el Sindicat dArtistes Teatrals de Barcelona obtingué una subvencio "amb caracter permanent" de 1.50o pessetes per organebrer 1932]: 155)
Catalunya (90 representacions). Entre altres aspectes, també havien d'adduir el programa dels títols que representarien, en el qual s'especifiqués les estrenes de textos d'autors catalans, les represes de peces de repertori i la representació d'obres estrangeres que signifiquessin una aportació qualifícada a l'escena catalana. A més, l'empresa que guanyés el concurs havia de comprometre's a representar els títols guardonats al premi Ignasi Iglésias de 1933 i I934; havia d'estar disposada a establir una cooperació amb la Institució del Teatre i les companyies d'aficionats; havia d'organitzar funcions populars, amb preus reduïts, per posar a l'abast de tots els estaments socials l'assistència al teatre, i havia de preveure també funcions per al públic infantil adreçades a les escoles públiques. En el termini previst, el de is de juny de i934, el Comitè de Teatre optà per concedir la subvenció a l'empresa Nicolau-Aluges després d'una "laboriosíssima" discussió ("La subvenció per a la vinent temporada"). ${ }^{4}$

La segona branca de la política teatral republicana fou l'intent de reorganitzar els serveis de la Institució del Teatre, que passà a dependre de la Generalitat de Catalunya. Ben aviat, el govern català acordà, amb data del 9 de juny de 1931, de constituir-ne un nou Patronat que seria integrat per Francesc Macià, com a president del Govern; Ventura Gassol, com a conseller d'Instrucció pública; Joan Puig i Ferreter i Pere Coromines Muntanya, en qualitat de diputats de la Generalitat, i Pompeu Crehuet i Josep M. Millàs i Raurell, com a ciutadans de Barcelona (Generalitat, Report del Govern 308). Mentre encara estava pendent d'assignar les consignacions pressupostàries, el govern català subvencionà les despeses de la Institució del Teatre i hi féu diversos nomenaments: encomanà a Marc Bertran i Tintorer la direcció del Museu i a Joaquim Pena, la de la Biblioteca i els Arxius ( $B G C$ I [Is gener 1932]: 9, i 2 [Is febrer 1932]: 66); nomenà Lluís Masriera, en representació de la Junta de Museus de Barcelona, membre del Patronat ( $B G C_{2}$ [30 gener 1932]: 29), i, en substitució d'Adrià Gual, designà Joan Alavedra i Seguranyes com a director de la Institució del Teatre, amb un sou de 6.000 pessetes anuals (ordre del 2 d'abril de 1934 , Butlletí Oficial de la Generalitat de Catalunya $\mathrm{I} 38$ [I8 maig 1934]: 1053). ${ }^{5}$

${ }^{4}$ De les tres empreses que sol-licitaren la subvenció, el Comitè de Teatre exclogué per unanimitat la dAntoni Piera perquè no reunia les condicions assenyalades en convocatoria del concurs. Després de rebutjar la proposta de Pous i Pages de deixar-lo desert, a la qual s'adherí Plana, els membres del Comite debateren durant tres hores sobre les altres dues sol-licituds: la de Climent Fernández Burgas (Romea) i la de Merce (a) Rotaren per la proposta de Nicolau-Aluges, que fou defensada sobretot per Millàs-
Raurell Pous i Pages.

5 El Consell de la Generalitat acceptà, el 31 de desembre de 1931 , la renúncia de 
El tercer eix de la política teatral republicana, el de la institucionalització del premi Ignasi Iglésias, es materialitzà el 8 d'agost de 1932 data en què la Conselleria de Cultura elevà a consagració oficial i aus picià el guardó de teatre, com també el de novel-la (Joan Crexells) i e nounat de poesia (Joaquim Folguera), amb l'objectiu de "fomentar la literatura dramàtica i enaltir amb ella el teatre català" ( $B G C$ I7 [Is setembre 1932]: 445-46). Dedicat a la memòria del "dramaturg del poble", el premi Iglésias tindria un caràcter anual, es concediria "a la millor obra dramàtica que s'hagi estrenat en el període comprès entre el ir d'octubre i el 30 de setembre de cada any", es fallaria el 3 de novembre i seria dotat amb la quantitat de 5.000 pessetes. Segons la disposició oficial, una comissió gestora, designada pel Consell de Cultura de la Generalitat, la Secció Filològica de l'Institut d'Estudis Catalans, l'Acadèmia de Bones Lletres i l'Associació Protectora de l'Ensenyança Catalana, decidiria cada any els cinc membres del jurat del premi. ${ }^{6}$ En la primera convocatòria de l'Iglésias, el jurat dictaminador, format per Joaquim Borralleras, Pere Coromines, Joan Cortès, Josep Farran i Mayoral i Josep Pous i Pagès, l'adjudicà a Josep Maria de Sagarra per $L$ 'Hostal de la Gloria (BGC 24 [30 desembre 1932]: 672).

Mentre la Generalitat de Catalunya aspirava a organitzar un pla general d'estímul a les lletres catalanes, Cultura renovà, la primavera de 1933, la convocatòria del premi Iglésias, així com la de la resta de guardons literaris dedicats a la poesia i a la novel.la (decret del is de maig de 1933, $B O G C 43$ [23 maig 1933]: 628). A diferència de l'edició anterior, la nova convocatòria de l'Iglésias admetia la possibilitat de presentar-hi també obres teatrals inèdites, establia que l'emissió del veredicte es fes durant la setmana del 18 al 23 de desembre i reservava el dret de la Generalitat a editar les obres premiades inèdites amb el benentès que els autors en rebrien el $15 \%$ del producte brut de la venda. L'Iglésias de I 933 fou adjudicat a Albert Piera i Serís per Els homes forts, que premià un urat constituit per Joan Alavedra, Cèsar August Jordana, Joan Puig Ferreter, Josep M. de Sagarra i Domènec Guansé (ordre del 28 de desembre de I933, BOGC II [II gener 1934]: I62). Malgrat que Gassol es com-

constar "la seva satisfacció pel zel i la competència demostrats en l'excrcici de l'esmentat càrrec") i el nomenament per a la plaça vacant d'Enric Giménez i Llovera (Generalitat, Report del Govern 310). D'altra banda, la Generalitat es féu càrrec de diverses despeses menors de la Instituco del Teatre, corresponents a lany 1931 i 1932, entre les quals I59; 9 [5 maig 1932]: 225; II [I5 juny 1932]: 278 i 281-82; I3 [I5 juliol I932]: 344 ; 24 [30 desembre 1932]: 671).

6 Retribuits convenientment amb 250 pessetes per la seva feina, els membres del jurat havien d'escollir l'obra guanyadora per votació secreta, a partir d'una primera tria cada torn fins que, en la cinquena votació, seria guanyadora l'obra de les dues que reunís la majoria de vots. prometé públicament que l'obra debutaria en la vetllada inaugural de la temporada de teatre català que patrocinaria la Generalitat, Els homes fort arribà als escenaris molt més tard: el 8 de gener de I935, al Teatre Poliorama, per la companyia subvencionada Nicolau-Martori ("Notes")

Les línies programàtiques tot just encetades pel Departament de Cultura que dirigia Gassol s'estroncaren a causa del Sis d'Octubre i el règim d'excepció que se'n derivà. Durant el Bienni Negre (1934-1935), la política teatral republicana es mantingué sota mínims. Es continuà concedint el premi Ignasi Iglésias corresponent al I934, ja convocat pel govern d'esquerres durant la primavera d'aquell any, sense modificarne substancialment les bases de les edicions anteriors, per bé que les "circumstàncies especials" motivaren l'ajornament de la data d'adjudicació, que es fixà el 15 de març de 1935 (ordre del 9 de maig de 1934 $B O G C_{146}(26$ maig 1934): I241, i ordre del 30 gener de $1935, B O G C 32$ [r febrer 1935]: 881-82). En l'edició de 1934, el guardó recaigué en Josep M. Millàs-Raurell per El món en què vivim, amb un jurat presidit per Josep Farran i Mayoral i integrat per Carles Riba, Albert Piera, Carles Capdevila i Francesc Trabal (ordre del 16 març de 1935, BOGC 78 [r9 març r935]: 2031-32). La convocatòria de l'Iglésias de r935 tampoc no modificà les bases que havien regit les edicions anteriors, per tal com es considerà que encara eren vàlides (fins i tot es mantingué l'assignació de 5.000 pessetes) (ordre del 16 juliol de 1935, BOGC 199 [I8 juliol 1935]: 47677). En aquesta ocasió, un jurat constituït per Josep M. Millàs-Raurell, Albert Piera, Carme Montoriol, Pompeu Crehuet i Màrius Gifreda concedí el premi a Nicolau M. Rubió per Un sospir de llibertat (ordre de l'i octubre de I935, BOGC 289 [16 octubre I935]: 48I-82, i ordre del 28 desembre de $1935, B O G C$ 364 [30 desembre 1935]: 2746).

La Conselleria de Cultura del govern de dretes tornà a rebatejar la Institució del Teatre de la Generalitat de Catalunya amb el seu primitiu nom d'Escola d'Art Dramàtic i, per decret, s'assegurà que la resolució de tots els assumptes relacionats amb el seu funcionament depenguessin del conseller de Cultura, el qual s'arrogava la facultat d'assistir a les reunions del Claustre de Professors en qualitat de president (decret del 20 abril de $1935, B O G C$ 12. [ I maig 1935]: 850)..$^{7}$ Més endavant, tanmateix, en una prova palmària del caire erràtic que prengué la política teatral durant el Bienni Negre, Duran i Ventosa decretà que fos resticuït e nom d" Institució del Teatre de la Generalitat de Catalunya" per tal que

El quadre d'ensenyaments per al curs 1935-1936 quedava constituït en tres branques actives, a dactors dramatics, la descenogratia i la de recitació una de pilot, la d'actors hrics, i una altra pendent per a mes endavant, la de dansa. Entre els professors, eren designats Enric Gimenez i Lloberes, per a les classes d actors dramàtics i de recitació Joaquim Montero, per a les classes d actors lírics; Enric de la Fuente, com a professode música de les classes d’actors lírics. 
no únicament respongués a la seva funció educativa, sinó també que potenciés el Museu i la Biblioteca i que se'n facilités la reorganització (decret del I8 juny de $1935, B O G C_{174}$ [23 juny 1935]: 2363).

El pas imperatiu d'un govern d'esquerres a un altre de dretes tingué, com és lògic, una concreció en el canvi de plantejaments en política teatral. En una nota de premsa publicada a la primeria de juliol de 1935, Duran i Ventosa manifestà la seva oposició "al sistema de fer viure una determinada empresa de teatre català, sigui la que sigui, mitjançant subvencions que tendeixin a la creació d'un Teatre Català Ofícial" i, després d'avançar que desactivaria el Comitè de Teatre, exposà clarament la seva aposta per la iniciativa privada ("La subvenció de la Generalitat"). El dirigent de la Lliga s'escudava en el fet que el teatre català, en temps de Guimerà o d'Iglésias, no havia necessitat la protecció del poder públic, de manera que, en plena recuperació nacional, el suport governatiu podia semblar una mostra d'impotència, i proposava d'estimular "la legítima competència d'empreses i companyies" amb un o diversos premis en metàl-lic que un jurat ad boc adjudicaria a aquelles empreses que, d'acord amb unes condicions generals, acreditessin haver-ho merescut al final de la temporada per la seva consagració a l'art dramàtic en català.

El canvi més important que introduí el nou conseller Duran i Ventosa fou, precisament, la dissolució del Comitè de Teatre de la Generalitat de Catalunya, l'aposta més decidida de la política teatral endegada per Gassol, amb el pretext que havia estat creat sense l'acord del Consel Executiu i amb l'argumentació que la seva actuació no havia "excel-lit en eficàcia, car és evident que en el concepte públic la realitat no ha correspost ni a la seva intenció ni a la importància del concurs prestat per la Generalitat per tal de donar moments de lluïment al nostre teatre" (ordre del 4 juliol de 1935, BOGC 190 [9 juliol 1935]: 208). ${ }^{8}$

No obstant les intencions de Duran i Ventosa, el Departament de Cultura es limità, seguint la tònica dels anys anteriors, a subvencionar, sense concurs públic 1 amb quantitats notablement reduides, una nova empresa, aquesta vegada la de Nicolau-Martori, amb la suma de 15.000 pessetes, perquè pogués actuar al Teatre Novetats durant la temporada 1935-1936 (ordre del I6 setembre de 1935, BOGC 26I [18 setembre 1935]:

${ }^{8}$ De fet, Puig i Ferreter, Ventós i Millàs-Raurell, membres del Comitè de Teatre, havien deixar automàticament de pertànyer-hi, quan, a causa del Sis d'Octubre, foren desposseits dels carrecs que representaven. Plana, en canvi, feia temps que se n'havia desentès públicament per discrepancies amb l'orientació que prenia. Rubió, Roviralta Palol no havien interingut mal, en realitat, en les actuacions del Comitè de Teatre gairebé sempre a l'oposició". O sigui que, com concloia La Publicitat "el Comitè de Teatre de la Genera itat era ara, una cosa mon con més que enterrar-la" ("Ha estat dissolt").
1994-95). La disposició publicada deixava clar que el conseller de Cultura no era favorable d'instituir un teatre oficial català "amb una forta subvenció i una intervenció directa de la Generalitat”. Ara bé, davant de la imminència de la nova temporada, havia optat per atendre la instància signada per Ramon Martori, en què reclamava un ajut per poder debutar al Novetats i, d'aquesta manera, assegurar que hi hagués representacions de teatre català a Barcelona. Anàlogament, per evitar greuges comparatius, el conseller decidí de fer cas de la petició raonada que li adreçà Pius Daví, en nom del conjunt escènic Vila-Daví, perquè gaudís d'un suport per a la temporada 1935-1936 al Teatre Romea i, atenent al crèdit innegable de la formació "en la seva llarga actuació per a l'enaltiment i el prestigi de l'escena catalana", li atorgà també una subvenció de I5.000 pessetes (ordre del 31 octubre de 1935, BOGC 309 [5 novembre 1935]: 1082-83).9 Com en el cas anterior, a desgrat de l'excepció feta amb les dues companyies, Duran i Ventosa exposà de manera diàfana que, al seu entendre, el teatre català "hauria de viure amb mitjans propis i en virtut d'iniciatives privades", un criteri que descartava de moment la creació d'un teatre oficial. ${ }^{\circ}$

Altrament, Cultura resolgué de manera favorable les instàncies que li adreçaren les entitats teatrals consagrades a la difusió del teatre català per poder rebre ajuts a les seves iniciatives. Concedí, per exemple, una subvenció important, 5.00o pessetes, a la Federació Catalana de Societats de Teatre Amateur (FCSTA), com a "entitat propagadora" de l'escena catalana que havia fet possible "l'estrena d'obres d'autors nous, la revelació d'actors i la valoració d'obres del nostre repertori", per subvenir a les despeses de l'organització dels concursos de teatre que celebrava i la seva actuació "en favor del teatre català en els seus diversos aspectes" (ordre del I8 octubre de 1935, BOGC 295 [22 octubre I935]: 657-658). En una línia semblant, el conseller determinà que fos atorgada a l'Associació de Teatre Selecte una subvenció de 2.000 pessetes per contribuir a les despeses motivades per la celebració de les festes d'homenatge a Apel-les Mestres, amb motiu dels seus 80 anys, "un nom que representa en el nostre moviment artístic no un moment, ni una època, sinó una continuïtat exemplar i un procés constant de

9 La Conselleria concedí també un ajut de 4.800 pessetes a Enric Lluelles, director de la Companyia de Teatre Català amb seu a la Sala Studium de Barcelona, perquè pogués emprendre una tournée per les comarques catalanes, per les Illes i pel Migdia de desembre I935]: 2083).

1o Abans de fixar el règim de subvencions, Duran i Ventosa encarregà a Alexandre I Ales Soldevila un projecte de bases per protegir el teatre catala (Plana).

"Altres disposicions menors: la concessió d'una mensualitat de iso pessetes, a
arec de la partida "Subvencions a artistes catalans impossibilitats per al seu art", al vell càrrec de la partida "Subvencions a artistes catalans impossibilitats per al seu art", al vel.
actor Pep Marquès (ordre del 26 octubre de 1935, BOGC 300 [27 Octubre 1935]: 827-28). 
superació" (ordre del to setembre de 1935, BOGC 314 [1o novembre 1935]: $1275-76) .^{12}$

Entre despatxos, Duran i Ventosa es preguntava quina seria la millor solució per assegurar una temporada artísticament digna de teatre català $i$, en una carta adreçada a Ramon Coll i Rodés, alcalde de Barcelona, amb data del 4 de febrer de 1936 , exposava les quatre possibilitats que entreveia: (a) concedir un premi, en acabar la temporada, per a les empreses o companyies que, d'acord amb unes condicions generals, haguessin treballat per l'art dramàtic en llengua catalana; (b) subvencionar, per mitjà d'un concurs públic, una determinada companyia, sota el control del Comitè de Teatre (aleshores dissolt); (c) oferir petites subvencions - com havia fet aquella temporada la Conselleria- a les companyies que, amb prou garanties artístiques, es disposaven a fer teatre català, i d) adquirir, arrendar o construir un teatre $i$, també per concurs públic, cedir-lo a les companyies que programessin en català (Carta). Després d'estudiar les diverses fórmules, l'impulsor del projecte del Teatre de la Ciutat (I921) es decantava per la darrera perquè era la que considerava més pràctica i la que oferia més garanties, però, com que es tractava d'una empresa d'envergadura i reclamava una inversió econòmica important, creia que havia de ser patrocina$\mathrm{da}$ conjuntament amb el consistori barceloní.

La represa de la "normalitat" estatutària deixà molt poc marge per a l'actuació efectiva de Gassol al capdavant, de nou, de la Conselleria de Cultura. Abans de l'esclat bèllic i revolucionari, Gassol tingué temps, tot just, de restituir els membres —amb l'excepció, naturalment, de la presidència que passava a Lluís Companys- del Patronat de la Institució del Teatre, encarregat d'estudiar i redactar el projecte de reorganització de l'entitat, que havien estat designats pel Consell Executiu el 9 de juny de 1931 i el 18 de gener de 1932 , i de reposar en el seu càrrec de director Joan Alavedra i Seguranyes (ordre del 6 març de I936, BOGC 7I [1 març 1936]: 19I4, i ordre del I4 març de 1936, BOGC 77 [I7 març 1936]: 2034). La primavera de 1936, Gassol anuncià un ambiciós pla d'actuació que havia de començar a executar-se a partir de l'octubre, amb el nou curs acadèmic, i que aspirava a ampliar l'eficàcia de la Institució del Teatre. ${ }^{13} \mathrm{El}$ pla projectava no tan sols de revisar els aspectes docents del centre, sinó sobretot d'erigir-lo en una mena d'organisme oficial aglutinant de les entitats artístiques i culturals catalanes

${ }^{12}$ L'Associació de Teatre Selecte de Barcelona ja havia rebut, el 28 de setembre de 931, una subrenció de 1.000 pessetes per contribur a les despeses de la celebració a (Generalitat, L obra 337 ).

${ }^{13} \mathrm{El}$ projecte de la Conselleria de Cultura d'instal-lar, d'acord amb l'A juntament de del Teatre i un estatge dedicat a l'escena amateur, fou desestimat (Gassol) dedicades a les arts escèniques, que es preveia que disposarien de representació en el Patronat ("Reorganització"). La premsa interpretà que la Institució del Teatre controlaria tota la intervenció de la Generalitat en la vida teatral, tal com recollia el titular de la nota oficial publicada per la secció "Escenaris" d'Última Hora del 9 de maig, fet que obligà Gassol a aclarir l'abast de la reorganització: es limitava, de moment, a "l'ensenyament dramàtic ... pres sota el seu angle més vastíssim; volem que la Institució del Teatre no sigui pas una escola freda i encarcarada, sinó un centre viu d'experimentació, d'assaig" (Artís, "Tot parlant”). Gassol anuncià la recuperació de l'entente amb l'Ajuntament de Barcelona, a través de Cristià Cortès (conseller municipal de Cultura), per garantir, com s'havia fet dos anys enrere, l'estímul a les companyies catalanes, però matisà que no pensaven fer cap pas sense abans reunir-se i escoltar la veu de "tots aquells elements - autors, crítics, actors, etc.- que, ultra llur capacitat reconeguda, han demostrat reiteradament l'interès que senten per l'esdevenidor del teatre català" (Artís, "Tot parlant")

A l'estiu de 1936, el Departament de Cultura renovà també la convocatòria del premi Ignasi Iglésias de teatre, com també de la resta dels premis literaris i dels de nova creació (el Joan Maragall d'assaig), amb l'única novetat que el guardó no es podia deixar desert ni repartir-ne l'import (decret del 9 juny de 1936, $B O G C$ I7I [is juny 1936]: 2180-81). Gassol volgué reprendre, així mateix, el projecte, iniciat el 1934, d'establir "una protecció oficial permanent" al teatre català que pal-liés la descohesió de les companyies, de manera que acordà, amb l'A juntament de Barcelona, d'obrir un concurs per subvencionar una temporada de teatre català en què podien concórrer totes les companyies dramàtiques catalanes (ordre de l'r juliol de 1936, BOGC 190 [8 juliol 1936]: 245-46). Abans de prendre aquesta resolució, Gassol convocà diversos dramaturgs, directors d'escena i crítics teatrals a la Conselleria de Cultura per tal de conèixer el seu criteri respecte a l'estímul que les corporacions públiques oferien al teatre català. Els reunits coincidiren en la necessitat que, en el futur, s'encarrilessin d'una manera definitiva les activitats teatrals catalanes, però que la imminència de la temporada i l'estat de l'escena indígena feien aconsellable "una solució d'urgència consistent a subvencionar una companyia catalana en una forma més o menys sembiant a l'adaptada en aquella primera experiència de l'any I934" ("Subvencionarà")..$^{\text {I4 }}$

${ }^{14}$ Gassol recollí també el suggeriment de celebrar, cap al mes de setembre del mateix any 1936, un congrés de teatre a Barcelona, en que participarien tots els agents interessats en el millorament de lescena catalana i del qual podria sortir limpuls decisiu per a l'actuació de la Generalitat i l'A juntament a fi de "siruar el teatre català al lloc altíssim que li pertoca entre les nostres institucions de Cultura" ("Un Congrés"). 
L'articulat de l'ordre oficial reconeixia que es tractava d'una mesura provisional que assegurés almenys el funcionament regular d'un teatre català, que permetés de coordinar els valors dispersos i que assenyalés unes orientacions, mentre s'esperava l'avinentesa anhelada "d'alçar l'edifici que serà la seu de la nostra gloriosa institució nacional". La companyia subvencionada, a la qual es concediria 50.000 pessetes, s'obligava a programar, a partir de la segona desena d'octubre de 1936, una sèrie de I20 funcions de nit en un teatre de primera categoria de Barcelona i a estrenar l'obra que hagués obtingut el premi Ignasi Iglésias de 1936. La Conselleria de Cultura i l'Ajuntament de Barcelona anunciarien, a la darreria de desembre, un segon concurs amb les mateixes finalitat i condicions que el primer, en el qual es podia presentar també la companyia guanyadora, per tal de donar continuiltat a la temporada oficial durant el primer semestre de 1937. Entre les condicions de programació, cal destacar el fet que la proporció d'obres estrangeres en el programa general de la temporada no podia ser superior a la d'una per cada tres peces catalanes. ${ }^{15} \mathrm{La}$ socialització dels espectacles públics derivada de la nova conjuntura bèl-lica i revolucionària obligà el Departament de Cultura a anul-lar la convocatòria del concurs.

A primeries de juliol del I936, en vigílies inesperades de l'esclat bèl-lic i revolucionari, Ignasi Agustí es féu ressò del rumor que rodava en els cenacles teatrals sobre el projecte, que la Generalitat volia dur a cap de manera immediata, de construcció d'una gran sala d'espectacles, d'un "Teatre Nacional de Catalunya" (Agustí). La brama corria d'ençà que Gassol havia convocat al seu despatx la representació de la gent de teatre - -a què hem fet referència més amunt-i s'havia estès fins arribar als medis polítics i fer-se creible. Agustí assegurava que el rumor havia passat a ser una notícia ben fonamentada, car els impulsors de la idea, Ventura Gassol (Generalitat) i Carles Pi i Sunyer (Ajuntament), havien començat a treballar-hi de ferm. Fins al punt que, després de descartar - per raons econòmiques, atès el cost del traspàs- el solar que ocupaven els incendiats magatzems "El Siglo", s'ha-

${ }^{15}$ Pius Daví presentà una sol-licitud, en nom de la companyia Vila-Daví, en què exposava que, si bé constituïa un bon ajut per al desenvolupament de la temporada, la el lloguer del Teatre Novetats. Així i tor, la companyia faria tots els possibles per assolir la màxima categoria i dignitat artístiques: "Estrenes?... Dels millors autors, sense que això vulgui dir que sia barrat el pas als novells. A part de l'obra guanyadora del premi Ignasi Iglésias d'enguany, compta de moment, amb Sagarra, Millass-Raurell, Elies, Soldevila, Puig i Ferreter, Artís, Rubió Tudurí, Fontdevila, Bonavia, Vilaregut, Casanova, etc., etc. / Repertori?... El més extens i més genünament català que pugui presentar cap altra companyia. Les llargues actuacions que conjuntament han dut a terme, i que aquesta quedicollocada en un pla d'excep quo" (Thskencia). via decidit d'edificar-lo en l'espai — propietat de l'Ajuntament- de les antigues casernes de les Drassanes, en la confluència de les dues artèries més dinàmiques de la vida ciutadana: la Rambla i el Paral-lel. En opinió d'Agustí, el projecte serviria per recuperar un dels indrets més bells de la ciutat i tindria uns efectes positius per a la normalització de la vida teatral, per tal com, estalviant-se les subvencions a fons perdut, es disposaria en contrapartida d'un teatre propi. Fos quin fos l'estadi de concreció en què es trobava aquest propòsit institucional d'edificar un teatre nacional de bell nou -una idea debatuda intensament en l'enquesta sobre el teatre municipal de 1907 i també arran del projecte de Teatre de la Ciutat de I92I-, l'esclat bèl-lic i revolucionari i l'organització socialitzada que s'instaurà exigiren d'ajornar-lo sine die.

\section{DeBats}

Durant els anys 1931-1936, la política de la Generalitat republicana en relació amb les arts escèniques ocupà el centre del debat teatral. Passada l'eufòria derivada de la proclamació de la República el i4 d'abril, la nova temporada 193I-I932 venia marcada per la crisi del teatre que es feia sentir en els escenaris d'arreu d'Europa (París, Londres, Berlín), on els empresaris reclamaven a la desesperada la protecció de l'estat, però en el cas català feia necessari, com reclamà Joan Cortès, una gran gosadia $i$ generositat de l'empresariat teatral per "jugar fort" en moments de prova (Codorniu). Amb la represa de l'activitat cultural, Cortès afirmà que era l'hora també que l'Ajuntament de Barcelona i la Generalitat de Catalunya atenguessin la fretura de crear una "escena oficial", tot i les dificultats que implicava a causa de la manca d'una "tradició clàssica nacional" en què emmirallar-se, de resultes del "llarguíssim eclipsi" que havia sofert la "vida nacional" (Cortès, "Del teatre"). Al fil d'aquestes reflexions, Carles Soldevila expressà la necessitat que els poders públics es plantegessin si volien, o no, organitzar la protecció eficaç del teatre català per assegurar-ne la continuittat, tal com feien les escenes de països com ara la Unió de Repúbliques Socialistes Soviètiques, Itàlia, Alemanya, França o Espanya, ja que a tot arreu el teatre estava estretament vinculat a l'existència nacional i, en plena crisi, no podia sobreviure sense "l'auxili de l'Estat": "si els pobles adults, sense problemes de reivindicació nacional, realitzen aquests esforços, com podríem nosaltres -es preguntava - plegar-nos de braços refiats de la iniciativa particular que enlloc abasta i que per a Catalunya s'ha manifestat importantíssima?" (Soldevila). Cortès creia, també, que, en el context d'una crisi del teatre d'abast mundial, es feia més imprescindible que mai una intervenció oficial que actués de manera reflexiva i prudent i que defugís de projectes - com el de la nacionalització del Liceu- d'una ambició 
desproporcionada als objectius i a la realitat de l'escena: "No creiem pas que sigui amb tartarinismes $i$ enfervoriments patriòtics a raig fet, bo i exprement els cabals del comú sense cap mesura ni cap sentit de ridícul, que s'hagi de vitalitzar el nostre depauperat teatre" (Cortès, "Tornem").

L'establiment d'un teatre oficial exigia de plantejar-se quin repertori hauria de programar per "orientar", "educar" i servir d" escola" als dramaturgs, als actors i al públic; un repertori que no tan sols consagrés els pocs autors de la pròpia tradició, sinó que també anostrés els millors clàssics universals (Cortès, "Del teatre"; Cortès, "Reflexions"). Lluny d'experiments estètics i de temptacions mercantilistes, el teatre oficial havia d'aspirar a I'“alliçonament constant" que es derivés d'un "repertori fonamental", integrat sobretot per textos d'innegable qualitat "de tot arreu i de tots els temps", atesa la carestia de la tradició teatral catalana: "Bones traduccions d'obres ben seleccionades del teatre isabel anglès, del francès del gran segle, dels grecs o dels llatins, dels italians, dels alemanys i dels russos, de tota aquella riquesa que podem anar a saquejar a mans plenes sense por d'arribar a exhaurir-la mai, haurien de fer molt i molt per a l'elevació del to, per a l'afinament de la sensibilitat, per a la correcció del gust, per a l'educació de la intel·ligència de la nostra gent de teatre tota i el seu públic, en posar-los al davant aquells bons models" (Cortès, "Noves reflexions")

Com no podia ser altrament en un context de polarització extrema, la política de subvencions a les empreses teatrals de la Generalitat despertà tota mena de suspicàcies i discrepàncies que sovint deixaven entreveure, a més de picabaralles de cenacles i divergències ideològiques, concepcions estètiques diferents i punts de vista oposats sobre la mena de repertori que havia de potenciar-se o el públic al qual calia adreçar-se. Tot i el consens més o menys unànime de la inevitabilitat de l'ajut oficial a l'escena catalana, com feien els sistemes teatrals dels paisos europeus, oi més si es volia garantir que fos present en la cartellera, la professió teatral mostrà les seves suspicàcies sobre la viabilitat d'aquesta solució. Andreu A. Artís criticà que la Generalitat s'hagués limitat a intentar salvar les empreses privades que es trobaven en fallida i a donar ales a "l'allau de poetes, novel-listes i crítics que s'han sentit comediògrafs i que no han aconseguit res més que amargar llur humor i avorrir el públic" (Artís, "Un teatre"). Josep Maria Planes qüestionà, a les envistes de la temporada 1934-1935, la imparcialitat de Comitè de Teatre -instituilt per Gassol- que havia de decidir la subvenció a una empresa teatral, ja que estava format per deu dramaturgs en actiu, i apostà per un "teatre de bulevard" que satisfés "els gustos de l'espectador mitjà" (Planes, "Teatre"). Carles Capdevila defensà que la subvenció fos un incentiu per als empresaris teatrals amb vocació isolvència contrastades, dilucidà els problemes pràctics (limitació de locals, empreses i companyies, quantia econòmica de les subvencions) que presentava la protecció al teatre català $i$, com a mesura provisòria de cara a la creació d'un teatre oficial, optà perquè s'afavorís dues empreses amb capacitat de risc per estimular-ne l'emulació $\mathrm{i}$ ampliar el potencial de l'escena catalana (Capdevila, "La protecció"). El mateix Planes considerà que la política subvencionadora de Duran i Ventosa estava abocada al fracàs, ja que duia els directors de les companyies a confiar en els "rosegons" de la subvenció i contribuïa a desmoralitzar "el petit món, ja prou confusionari, del teatre català" (Planes, "La qüestió"). Alexandre Plana, molt més conciliador, remarcà que Duran i Ventosa feia gala d'un optimisme excessiu quan declarava que el teatre català podia sobreviure sense el suport oficial i argumentà que, vistos els dèficits estructurals de l'escena indígena i el desinflament de la tensió nacional, es feia indispensable l'ajut oficial, com qualsevol altra manifestació artística, a una temporada de teatre català (Plana). A més a més, al seu entendre, seria una contradicció flagrant deixar de garantir que la cartellera disposés de teatre català, quan la Generalitat mantenia la Institució del Teatre, encara que fos amb una xifra modesta de 37.000 pessetes i encara que la seva activitat passés més aviat desapercebuda: "al parecer tiene la misión de estimular las escasas vocaciones que se manifiestan para el arte escénico. Si estas vocaciones no han de tener un cauce de viabilidad, pasando a una escena cualquiera, ¿para qué serviría aquella institución? No es que pidamos que se disuelva. Todo lo contrario. Convendría que se ampliase y reformase para asegurar su eficacia" (Plana)

Les diverses convocatòries del premi Ignasi Iglésias durant aquests primers anys republicans no estigueren tampoc exemptes de polèmiques. Francesc Curet, director de la revista Teatre Català, avalava la institucionalització del premi, però creia restrictiu que es limités només a les obres estrenades, atès que això no en garantia necessàriament la qualitat (Curet, "El premi"). Arran d'haver guanyat Sagarra la primera edició de l'Iglésias, Curet opinà que el guardó havia de destinar-se a recompensar únicament els autors novells, perquè, si- no, com havia passat en la primera convocatòria, la presentació d'obres que havien gaudit de l'aplaudiment del públic condicionava en excés la tria $\mathrm{i}$ desvirtuava la finalitat del guardó: "Que el premi fos atorgat a Sagarra o a Soldevila per una obra estrenada i premiada ja per l'aplaudiment reiterat i entusiasta del públic, suprem àrbitre, no representava cap guany ni avanç per al teatre català, puix sense el premi i abans d'instituir-lo havien escrit i posat en escena, amb èxit indiscutible, les seves produccions" (Curet, "A l'entorn"). Curet proposà de modificar les bases del concurs, a fi que s'evités que, en les edicions posteriors, hi acudissin tan sols obres que havien estat "un èxit esclatant" o que eren escrites per "megalòmans" o "analfabets", i que hi optessin només peces 
inèdites o no representades en teatres regulars. Si L'Hostal de la Glòria de Sagarra, i Un pare de família, de Soldevila, havien estat les dues obres més ben valorades, el jurat es devia haver trobat - concloïa Curetdavant d'una "evident penúria de la producció teatral catalana", atenent a l'evidència que ni l'una ni l'altra podien "ser enlairades a la categoria d'aquelles obres que són un exponent o el guiatge d'una dramàtica en camín" ("Unes paraules"). Les queixes de Curet devien tenir el seu efecte, perquè les bases de la segona edició del premi admetien la presentació de textos inèdits i, per acabar-ho d'arrodonir, el guardó fou adjudicat, contra tot pronòstic, a Albert Piera, un autor desconegut. Rafael Tasis i Marca s'apressà a aclarir que es tractava d'un dramaturg ben preparat $i$ amb idees pròpies que podia convertir-se en una nova revelació per a la dramatúrgia catalana (Tasis). Carles Capdevila també es féu ressò de la sorpresa que havia produit la concessió de l'Iglésias a un escriptor ignot i del revifament de la curiositat cap al teatre català, però es condolgué que s'hagués escaigut en un moment en què no hi havia cap teatre en disposició d'estrenar l'obra premiada (Capdevila, "Punts de vista").

La impossibilitat d'estrenar professionalment les obres aureolades amb l'Iglésias, ni en els escenaris subvencionats, fou una de les crítiques més constants a l'eficàcia real del premi. Puig i Ferreter, per exemple, contraposava el gran nombre de textos presentats a l'Ignasi Iglésias de r935 amb el fet que el Teatre Novetats, escena subvencionada, no comencés la temporada amb l'estrena d'un autor català (Puig). Alguns dels guanyadors de l'Iglésias, al seu torn, en qüestionaren més o menys explícitament la incidencia en l'escena professional $i$, en algun cas, fins oferiren alternatives per a la viabilitat escènica de les obres. Rubió proposava que cada membre del jurat del premi n'escollís dues, una més literària i l'altra més teatral, i que les deu resultants s'estrenessin, sota la direcció dels autors respectius, en un teatre petit, per deu formacions que concorreguessin en un concurs subvencionat per l'erari públic ("L'organització"). Millàs-Raurell deduïa que el premi es mostrava del tot ineficaç en un teatre català amb "ales de fang", perquè els textos eren rebutjats pels empresaris, que els tenien per "obres d'art" irrepresentables $i$, en canvi, trobaven refugi en l'escena amateur ("El premi"). Piera alertava del fet que l'“apoteosi d'obres còmiques leugeres" que passaven per "teatre popular" podria desprestigiar la dramatúrgia catalana, fer-la "sinònim de vulgaritat i de xaronisme", tot deixant al marge de l'escena professional els darrers guanyadors de l'Iglésias - Millàs-Raurell, Rubió- $\mathrm{i}$ àdhuc un autor consagrat com Puig i Ferreter (Piera). Altres veus coincidien, encara, que calia garantir que les obres guardonades es representessin en els teatres professionals o, si més no, "oficialment subvencionats", ni que això comportés reformar les bases del premi ("Una reforma"). Curiosament, en un context ben diferent, la petició dels cenacles teatrals republicans s'acompliria de manera excepcional amb l'estrena de La fam, de Joan Oliver, l'estiu del 1938, un text que s'endugué el premi del Teatre Català de la Comèdia nascut de la polèmica que generà el desert de l'Iglésias de r937 (Foguet, Teatre)

\section{BALANÇ}

La política cultural republicana féu un esforç notable per institucionalitzar, en l'àmbit del teatre, els mecanismes de què disposava l'escena catalana coetània a fi d'afiançar uns mínims d'estabilitat i de presència pública: la programació de teatre català en la cartellera de cada temporada, l'estímul de textos nous amb el premi Ignasi Iglésias $o$, a través de la Institució del Teatre, la formació artística de noves fornades de professionals. A més, la constitució del Comitè de Teatre, que tingué molt poca capacitat de reacció, i l'intent de donar més visibilitat pública a la Institució del Teatre, tot volent-la convertir en un organisme aglutinant de l'acció teatral governativa, eren mesures incipients que, amb més temps $\mathrm{i}$ amb més recursos, podien haver articulat els projectes en què somniava Gassol. És cert que la retòrica dels discursos oficials contrastava amb la migradesa de les realitzacions efectives - condicionades per les intermitències polítiques - i amb l'exigència teòrica dels debats, molt deutors de les lluites intestines de cenacles $\mathrm{i}$ les dissensions ideològiques de fons. Ara bé, la crisi de l'escena europea, particularment intensa en el teatre català pels seus dèficits estructurals, les enormes limitacions pressupostàries de la Generalitat i els virulents trasbalsos d'una situació politicosocial convulsa no permetien, ben mirat, de fer-se gaires il.lusions. Els problemes bàsics amb què topava la protecció oficial del teatre català -la feblesa congènita de l'empresariat, la inconsistència artística i professional de les companyies que mai no acomplien les expectatives inicials, la manca de locals ben equipats, les dificultats de crear un repertori i una dramatúrgia eficaços, la fluctuació del públic teatral- eren ben reals i no es podien resoldre d'un dia a l'altre: la urgència de cada temporada reclamava apuntalar econòmicament empreses i companyies per mantenir, si més no, una presència mínima de teatre català en la cartellera. El parèntesi involucionista del Bienni Negre estroncà les línies programàtiques encetades i l'esclat de la Guerra i la Revolució obligà a adaptar-les a una situació del tot inèdita.

FRANCESC FOGUE'T

UNIVERSITAT AUTONOMA DE BARCELONA 


\section{REFERENCIES}

Agustí, Ignasi. "Cap a l'edificació del Teatre Nacional de Catalunya? Segons rumors, la Generalitat té el projecte d'emprendre molt aviat la construcció i edificació d'una magnífica gran sala d'espectacles". L'Instant 6 juliol 1936: 4 .

ARTís, Andreu A. "Un teatre subvencionat". Mirador I8r (2I juliol 1932): 5.

-. "Tot parlant de teatre amb el conseller de Cultura: "Pensem estimular les companyies catalanes, però abans escoltarem l'opinió de tothom"'. Ultima Hora 12 maig 1936: 7.

"A tots els pobles, el teatre és el triomf de la paraula - - ha dit Ventura Gassol en el seu bell parlament. L'homenatge a Maria Vila i Pius Daví". La Humanitat I2 juny 1936: 6.

Bransuela, Lluís M. "El comitè de teatre de la Generalitat de Catalunya". ATS 2, extraordinari (març-abril 1934): 4.

Butlleti de la Generalitat de Catalunya r-24 (1931-1932).

Butlletí Oficial de la Generalitat de Catalunya II-364 (1933-1936)

Capdevila, Carles. "Punts de vista. De teatre català". Mirador 257 (4 gener 1934): 5 i 8

-. "La protecció al teatre català". La Publicitat 28 juny 1935: 8; 30 juny 1935: 6; 7 juliol 1935: 10; 12 juliol $1935: 8$ i I4 juliol I935: II.

Carta de Lluís Duran i Ventosa a Ramon Coll i Rodés, datada a Barcelona, 4 febrer 1936. Arxiu Històric de la Diputació de Barcelona, lligall Q-23, exp. 22I.

CoCA, Jordi; Gallén, Enric; Vàzquez, Anna. La Generalitat republicana $i$ el teatre (1931-1939). Legislació. Barcelona: Publicacions de l'Institut del Teatre, 1982.

CoDorniu [Joan Cortès]. "La República i el Teatre". Mirador I28 (I6 juliol I93I): 5 .

CORTĖs, Joan. "Del teatre oficial". Mirador 134 (27 agost r931): 5 .

- "Tornem a parlar-ne. La misèria del teatre catalâ". Mirador $252(30$ setembre 1933 ): 5 .

-. "Reflexions sobre el repertori. Del teatre oficial". Mirador 339 (Is agost 1935): 5 .

-. "Noves reflexions sobre el repertori". Mirador 363 (30 gener 1936): 5 .

CURET, Francesc. "El premi Ignasi Iglésias". Teatre Català 2 (8 octubre 1932): 19-21.

-. "A l'entorn del Premi Ignasi Iglésias". Teatre Català I2 (I7 desembre 1932): 179 .

-. "Unes paraules més sobre el Premi Ignasi Iglésias". Teatre Català I4 (3I desembre 1932): 2II.

"El premi Ignasi Iglésias vist per Millàs-Raurell. El teatre català -diu- dóna la impressió de tenir ales de fang”. La Publicitat II febrer 1936: I2.
FOGUET, Francesc. Teatre, guerra i revolució. Barcelona, 1936-1939. Barcelona: Publicacions de l'Abadia de Montserrat, 2005.

-. "La nacionalització del Gran Teatre del Liceu (I93I-I936)". Revista de Catalunya 246 (gener 2009): 9-2r.

GASSOL, Ventura. "L'obra de cultura dels governs d'esquerra de la Generalitat. Des del penal de Cartagena". La Humanitat i3 febrer 1936: 4-5.

Generalitat de Catalunya. Report del Govern. Decrets de la presidència. Acords de la Diputació. Acords del Consell. Barcelona: Impremta de la Casa de la Caritat, 1932.

-. L'obra de cultura. Barcelona: Tipografia Occitània, 1932.

"Ha estat dissolt el Comitè de Teatre de la Generalitat". La Publicitat Io juliol I935: 8.

Instància signada per Pius Daví, a Barcelona, el 28 de juliol de 1936 Arxiu Històric de la Diputació de Barcelona, lligall Q-23, exp. 221.

"La Generalitat fa públiques les condicions del concurs a la subvenció creada per a teatre català". La Veu de Catalunya 3I març 1934: 5.

"L'organització del Premi Ignasi Iglésies. El que diu Nicolau Maria Rubió". La Publicitat 4 febrer 1936: 8

"La subvenció de la Generalitat al Teatre Català". La Ven de Catalunya 7 juliol i935: ir.

"La subvenció per a la vinent temporada de Teatre Català és concedida a l'actriu Mercè Nicolau". La Veu de Catalunya I7 juny 1934: 4

"Notes i comentaris. I els bomes forts, què?" Mirador 306 (22 desembre 1934): 8.

PIERA, Albert. "On va el teatre català. Crit d'alerta". La Publicitat I9 febrer 1936: 9.

PlanA, Alejandro. "La protección al Teatro Catalán. Por la dignidad de la escena". La Vanguardia 21 juliol 1935: 6.

PLANES, Josep Maria. "Teatre català subvencionat". Mirador 28I (2 juny 1934): 5 .

-. "La qüestió del teatre". La Publicitat I2 març 1936: r.

PUIG I FERRETER, Joan. “Tanta misèria, doncs?” El Diluvio 27 octubre 1935: 5-6. Recollit a Joan Puig i Ferreter. Textos sobre teatre. A cura de Guillem-Jordi Graells. Barcelona: Institut del Teatre, I982. I2628 .

"Reorganització de la Institució del Teatre de la Generalitat. Projectes ...". La Publicitat 1o maig 1936: 10.

SOLDEVILA, Carles. "El temps ens ho dirà". La Publicitat I7 setembre 1932. Recollit a Carles Soldevila. Fulls de dietari. Una antologia. Tria i edició de Núria Santamaria. Barcelona: Empúries, 2004 $390-92$.

"Subvencionarà la Generalitat una temporada de Teatre Català? Pro teatre català". La Humanitat 18 juny 1936: 2. 
TASIS I MARCA, Rafael. "Un autor teatral desconegut. El premi Iglésies". Mirador 256 (28 desembre 1933): 5 .

"Un Congrés de Teatre per al vinent mes de setembre. Es tractarà del millorament del teatre català". Ultima Hora 19 juny 1936: 7.

"Una reforma urgent". Última Hora 30 març 1936: 11. 